\title{
Modified Light Concrete of High Strength
}

\author{
Katerina Pushkarova, Kostiantyn Kaverin", and Danilo Gadayuchyk \\ Kyiv National University of Constructioni Architecture, Povitroflotsky avenue, 31, Kiev, Ukraine, \\ 03037
}

\begin{abstract}
The study is devoted to the development of increased strength lightweight concrete based on Portland cement modified with a complex organo-siliceous additive containing a polycarboxylate superplasticizer and an active fine-ground siliceous component. The effect of this complex additive on the physical and chemical characteristics of the hydration and structure formation processes was investigated and it was shown that the high kinetics of the strength gain is provided by directional formation of low-basic calcium hydrosilicates, hydrogranates and plazolite, which are crystallo chemically similar to each other, and provide a dense and strength cement stone matrix. Modification by a complex additive makes possible to obtain concrete mixes with S4 consistency while a Portland cement consumption per $1 \mathrm{~m} 3$ of not more than $330 \mathrm{~kg}$, with a compressive strength of $55 \mathrm{MPa}$, watertightness up to W8, frost resistance up to F400, corrosion resistance coefficients $\mathrm{Kc}$ in the magnesium sulfate, sodium and ammonium solutions by 10 to $24 \%$. The introduction of a complex additive also helps to reduce the relative shrinkage by 16 to $19 \%$ compared to the control composition, which has a positive effect on the durability of the resulting concrete.
\end{abstract}

\section{Introduction}

As is already known, lightweight concrete based on expanded clay is used in prefabricated residential, transport and hydraulic construction. Also in the construction of port facilities, in shipbuilding, where, along with the reduction in the mass of structures, other positive properties of expanded clay concrete can be used: increased frost resistance, watertightness, resistance to aggressive exposure conditions.

Research in the field of lightweight expanded clay concrete was carried out by G.A. Buzhevich, A.I. Vaganov, V.M. Virovy, V.G. Dovzhik, V.A. Dorf, O.Sh. Kikawa, L.P. Orentlicher, T.M. Shtolle [1-6].

Abroad in this direction where the works of Rossignolo J. A, Morais J.A., Wee TiongHuan, Ergul Yasar, Cengiz Duran Atis, Alaettin Kilic, Hasan Gulsen, Jamal Alduaij, Niyazi Ugur Kockal, Ozturan T., Hugo Costa, Eduardo Julio, Lourenjo J. [7-14].

Fine mineral additives (microfillers) are an integral part of modern concrete, because their use allows reducing the consumption of cement, increasing the density, strength, resistance of concrete in aggressive environments to guarantee their durability. The positive results that are achieved when active mineral additives are introduced include the binding

\footnotetext{
* Corresponding author: 1krik.1k1@gmail.com
} 
of portlandite, the formation of low-base hydrosilicates, for example, the C-S-H phase, the reduction of the ratio of capillary and gel micropores in the structure of concrete, the intensification of hydration processes, and the regulation of temperature and volume deformations of cement compositions.

Examples of the practical implementation of additives in the technology of building materials using nanoscale structural elements are given in the papers of Yu.M. Bazhenov, P.G. Komohov, Yu.V. Pukharenko and others. They have showed significant effects achieved by the introduction of various nanoparticles. The trend is based on works by V.G. Batrakov, S.S. Kaprielov, M.A Sanitcky et al. [15-17], related to the modification of the cement stone structure by introducing microsilica and other dispersed mineral additives into the composition of raw mixtures, whose individual fractions can be classified as nanoparticles. The use of nano- and microsilica allows the use of additives along with the superplasticizer to significantly accelerate the processes of hydration and hardening of cement, to provide a high speed of strength gain and reach 115 to $150 \mathrm{MPa}$ by 28 days, increasing the durability of artificial stone by almost 2 to 2.5 times.

However, at the same time, issues related to the study of the replacement of the microsillica with its natural analogues and the study of compatibility with the latest class of superplasticizers based on polycarboxylates, polyacrylates and their esters, need further studying. Also, the issue about the influence of complex organosilicon additives on the processes of structuring high-strength lightweight expanded clay concrete and on their hardened properties still requires clarification.

The prospects for the use of high-strength lightweight concrete are in manufacturing of reinforced concrete products in industrial and high-rise civil engineering, the construction of road bridges, overpasses and interchanges, as well as in the construction of special purpose buildings, due to their positive qualities and advantages vs. heavy concrete. In addition, the reduction in the mass of structural elements of buildings allows solving complicated architectural problems and extends the scope of use of lightweight concrete as structural and insulation material.

Global experience in erection of buildings and structures with the use of structures made of expanded clay (Table 1) confirmed their reliability, durability and high performance of these structures.

Table 1. Comparison of properties of lightweight concrete used in different countries of the world.

\begin{tabular}{|c|c|c|c|c|}
\hline \multirow[b]{2}{*}{$\begin{array}{c}\text { Year of } \\
\text { implementation }\end{array}$} & \multirow[b]{2}{*}{ Land } & \multicolumn{3}{|c|}{ The main characteristics of light concrete } \\
\hline & & $\begin{array}{l}\text { Average density of } \\
\frac{\text { concrete, } \mathrm{kg} / \mathrm{m}^{3}}{\text { (bulk density of }} \\
\text { expanded clay) }\end{array}$ & $\begin{array}{c}\text { Strength } \\
\text { compression for } \\
28 \text { days, MPa }\end{array}$ & $\begin{array}{l}\text { Coefficient of } \\
\text { constructive } \\
\text { quality (C.C.Q.) }\end{array}$ \\
\hline 1995 & Norway & $\frac{\mathrm{D} 1700 \text { to } 1950}{\text { (M800 to } 1000)}$ & 60 to 79 & 35 to 40 \\
\hline 1997 & USA & $\frac{\text { D1450 to } 1800}{\text { (M400 to } 600)}$ & 18 to 46 & 12 to 26 \\
\hline 2002 & Germany & $\frac{\mathrm{D} 1800}{(\mathrm{M} 400)}$ & 14 to 25 & 7 to 14 \\
\hline 2003 & Brazil & $\frac{\mathrm{D} 1450 \text { to } 1600}{\text { (M400 to } 600)}$ & 40 to 50 & 27 to 31 \\
\hline 2003 & Turkey & $\frac{\mathrm{D} 1800 \text { to } 1860}{\text { (M600) }}$ & 30 to 40 & 17 to 22 \\
\hline 2004 & Japan & $\frac{\mathrm{D} 1800 \text { to } 1850}{\text { (M600 to } 800)}$ & 47 to 54 & 26 to 29 \\
\hline 2007 & Russia & $\frac{\mathrm{D} 1800}{(\mathrm{M} 600 \text { to } 800)}$ & 46 to 61 & 25 to 34 \\
\hline
\end{tabular}


The main precondition for the synthesis and durability of high-strength lightweight concrete is the modification of the cement matrix. In recent years, this has been usually achieved by the use of various complex additives, modifying both binder and concrete mixture.

In this regard, the development of effective high-strength lightweight expanded clay concrete, modified by complex organomineral additives, is a topical task. Consideration of the basic requirements for such additives, namely: component compatibility, availability in the Ukrainian market and the appropriate technical and economic justification for their application will increase the efficiency of using Portland cement. At the same time, the introduction of modified high-strength lightweight expanded clay concrete in monolithic construction requires the study of the peculiarities of the structure of this concrete, taking into account the effect of the compatibility of the action of silica additives of different nature with organic additives.

\section{Aim, research objectives, raw materials and research methods}

The purpose of the work is to study lightweight expanded clay mixtures based on Portland cement, modified by complex organosilicon additives, and obtaining on this basis high strength lightweight concrete with high physical, mechanical and operational properties.

To achieve this target, the following tasks must be solved:

- to carry out the analysis of already known information sources on the influence of organic and mineral admixtures on the properties of light concrete mixtures and the processes of structure formation during hardening of concrete;

- to develop the composition of a complex organosilicon additive and investigate the compatibility of its components by introducing it into concrete mixtures;

- to optimize the mix design of concrete mixtures and to study the properties of concrete mixtures and concrete.

The subject of the study is high-strength expanded claydite lightweight concrete LC 20/22 to LC 50/55 (DSTU B V.2.7-176: 2008) based on Portland cement modified by a complex organo-silica additive.

The following materials were used as raw materials: Portland cement, CEM I 42,5 R which complies with the requirements of Governmental Standard of Ukraine 2.7-46: 2010 produced by PJSC "Podilsky cement" (Gumentsi village, Ukraine); Dnieper quartz sand according to DSTU B V.2.7-32-95, with Fineness Modulus $=1.28$ (Kiev, Ukraine); expanded clay gravel of different grades, the results of which are given in Table 2.

All used silica additives by specific surface area are very finely dispersed, namely: byproducts of the Stakhanov Ferroalloy Plant (Blaine $=36,398 \mathrm{~cm}^{2} / \mathrm{g}$ ), OJSC ArcelorMittal Kryviy Rih (Blaine $=9,478 \mathrm{~cm}^{2} / \mathrm{g}$ ) and Elkem Microsilica Grade 940-U (Blaine = $=24,795 \mathrm{~cm}^{2} / \mathrm{g}$ ), SikaFume (Blaine $=8,556 \mathrm{~cm}^{2} / \mathrm{g}$ ), thin-melting glass "MHS" (Blaine $=$ $=10,485 \mathrm{~cm}^{2} / \mathrm{g}$ ), trepelle of the Konoplyansky quarry, ground for 2 hours in a ball mill (Blaine $=21,997 \mathrm{~cm}^{2} / \mathrm{g}$ ).

Polycarboxylate superplasticizers "ViscoCrete-5-600UA", "Plast 555W" (produced by TM Sika, Kiev, Ukraine) and "PowerFlow 3100", "PowerFlow 2695" (produced by TM MC-Bauchemie, Berezan, Ukraine) were used as plasticizers. They meet the requirements of DSTU B V.2.7-69-98, DSTU B V.2.7-171: 2008 (EN 934-2: 2001, NEQ).

The mix design procedure of lightweight concrete was carried out in accordance with DSTU B V.2.7-69-98, DSTU B V.2.7-114-2002, DSTU B V.2.7-176: 2008, DSTU B V.2.7-215: 2009 and mathematical experiment planning methods were used.

The rheological properties of concrete mixtures were determined according to DSTU B V.2.7-114-2002, DSTU B V.2.7-176: 2008. The physical and mechanical properties of the mortar $(40 \times 40 \times 160 \mathrm{~mm})$ and concrete $(100 \times 100 \times 100 \mathrm{~mm})$ were determined according 
to DSTU B V.2.7-187: 2009 and DSTU B V.2.7-214: 2009, respectively. Open porosity, average density, water absorption and watertightness of concrete samples were determined according to the methods given in DSTU B B.2.7-170: 2009.

Table 2. Characteristics of expanded clay aggregate.

\begin{tabular}{|c|c|c|c|c|c|}
\hline \multirow{2}{*}{ Producer } & \multirow{2}{*}{$\begin{array}{c}\text { Bulk } \\
\text { dencity, } \\
\mathrm{kg} / \mathrm{m}^{3}\end{array}$} & \multirow{2}{*}{$\begin{array}{l}\text { Compressive } \\
\text { strength } \\
\text { (cylinder), } \\
\mathrm{MPa}\end{array}$} & \multirow{2}{*}{$\begin{array}{c}\text { Coefficient } \\
\text { of thermal } \\
\text { conductivity } \\
\lambda, \mathrm{W} / \mathrm{m} \cdot \mathrm{K}\end{array}$} & \multicolumn{2}{|c|}{$\begin{array}{c}\text { Grade according to } \\
\text { DSTU B V. } 2.7-17-95\end{array}$} \\
\hline & & & & $\begin{array}{l}\text { By bulk } \\
\text { dencity }\end{array}$ & $\begin{array}{c}\text { By } \\
\text { strength }\end{array}$ \\
\hline $\begin{array}{l}\text { "Plant of expanded clay gravel } \\
\text { Novokumol" JSC, Belarus }\end{array}$ & 360 & 1.65 & 0.092 & M400 & S75 \\
\hline $\begin{array}{c}\text { "Odessa Keramzite Plant" } \\
\text { OJSC }\end{array}$ & 460 & 1.81 & 0.1 & M500 & S75 \\
\hline $\begin{array}{c}\text { Khmelnitsky Keramzite Gravel } \\
\text { Plant Ltd }\end{array}$ & 600 & 3.03 & 0.12 & M600 & S125 \\
\hline
\end{tabular}

The degree of dispersion of the siliceous additive was estimated using the laser diffraction method on the laser granulometry Mastersizer 2000 Ver. 5.60 and on the Blaine measurement device according to DSTU EN 196-6: 2007. Microhardness of the contact zone "binder - aggregate" of high-strength concrete was determined using a micro-meter PMT-3. The evaluation of the durability of lightweight concrete was performed by studying the kinetics of the strength set, corrosion resistance (DSTU GOST 27677-2011), frost resistance (DSTU B V.2.7-49-96) and deformation of concrete shrinkage according to DSTU B V.2.7-216: 2009.

\section{Test results}

As previous studies show, the use of a complex organosilicon additive can improve the kinetics of strength gain, and the main regulation factor is the amount of fine-ground tripoli earth in the complex additive [18-20]. Optimization of the composition of lightweight expanded clay concrete, modified with a complex additive, which includes a fine additive based on ground tripoli earth and superplasticizer, was carried out with the use of threefactor three-level mathematical experiment design (Table 2), in which, the consumption of Portland cement (200 to $400 \mathrm{~kg}$ ) (X1), the content of fine-ground tripoli (5\% to $15 \%$ ) (X2) and the bulk density of expanded clay gravel (M400 to M600) (X3) were used as variable factors.

Table 3. Intervals of variation and values of variable factors of concrete mixtures, modified with a complex organic-mineral additive.

\begin{tabular}{|c|c|c|c|c|c|}
\hline \multicolumn{2}{|c|}{ Factors, type } & \multicolumn{3}{c|}{ Variation levels } & \multirow{2}{*}{$\begin{array}{c}\text { Variation } \\
\text { intervals }\end{array}$} \\
\hline Natural & Coded & Upper & Middle & High & 0.1 \\
\hline Cement dosage, $\mathrm{t}$ & $\mathrm{X}_{1}$ & 0.4 & 0.3 & 0.2 & 5 \\
\hline Tripoli earth dosage, $\%$ & $\mathrm{X}_{2}$ & 15 & 10 & 5 & 100 \\
\hline $\begin{array}{c}\text { Grade of expanded clay } \\
\text { by bulk dencity }\end{array}$ & $\mathrm{X}_{3}$ & 600 & 500 & 400 & \\
\hline
\end{tabular}

By analyzing isoparametric diagrams (Fig. 1) of the change in compression strength of lightweight expanded clay concrete, it can be noted that the optimal values of the substitution amount is $10 \%$ tripoli of the mass of the binder.

By introducing a complex organic-silica additive with optimal composition and expanded clay M600 and higher makes possible, lightweight expanded clay concrete with compressive strength of 50 to $60 \mathrm{MPa}$ can be produced. 
The effectiveness of the modification of Portland cement compositions with a complex organic-silica additive is determined by the nature of the change in the microhardness of the contact zone: "binder - aggregate", the results of which are shown in Fig. 2.

Analysis of the data shows that the microhardness of the samples from unmodified Portland cement to section width of $20 \mu \mathrm{m}$ from nominal boundary grain filler is gradually increasing from $1,300 \mathrm{MPa}$ (filler) to 2,100 to $2,300 \mathrm{MPa}$ (cement stone), which is $20 \%$ higher than microhardness of stone mortar parts of concrete (Fig. 2, mix No. 1).

The modification of the expanded clay concrete by adding the superplasticizer "SikaPlast 555W" (Fig. 2, mix No. 2) increases the microhardness at the border with the aggregate to $2,450 \mathrm{MPa}$, which is $24 \%$ more than the microhardness of the same control mix.

a)

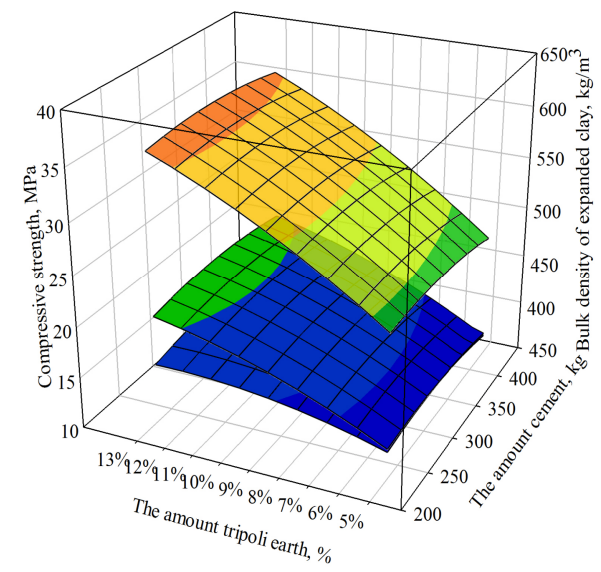

b)

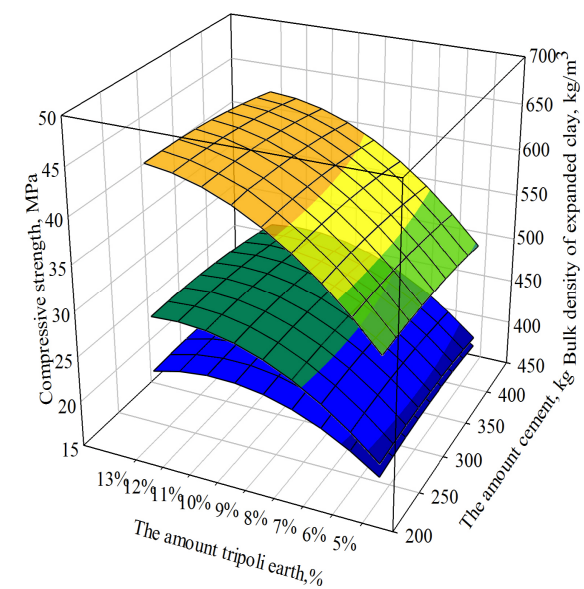

c)

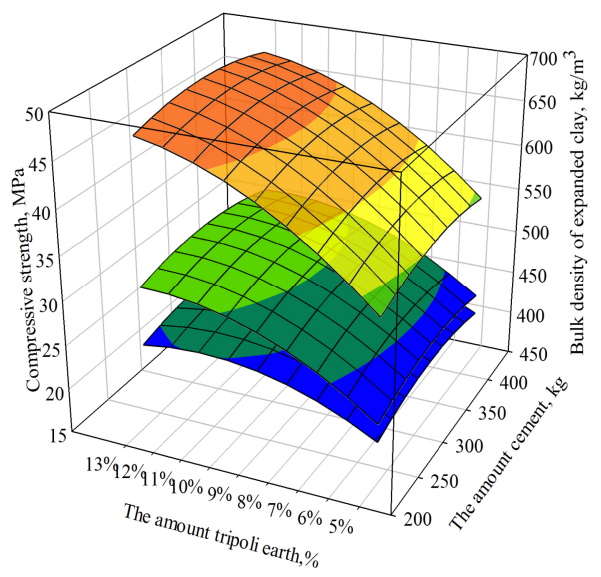

Fig. 1. Isoparametric diagrams of compression strength change for samples concrete on the basis of Portland cement, modified by a complex organo-silica additive based on superplasticizer "SikaPlast $555 \mathrm{~W}$ " in the amount of $1 \%$ and fine-ground tripoli earth (5 to $15 \%$ ), after hardening in normal conditions during 3 (a), 28 (b) and 365 (c) days.

With introducing a complex organo-silica additive into the lightweight expanded clay concrete (Fig. 2, mix No. 3), the microhardness value on the nominal grain boundary of the aggregate reaches $2,770 \mathrm{MPa}$, which is $32 \%$ more than the microhardness of the cement 
stone on the boundary of the grain and $19 \%$ more than the microhardness of the cementsand mortar in the intergranular space in comparison with the control mix. The compressive strength of such modified concrete increases by 25 to $30 \%$ vs. the composition without additive.

Modification of Portland cement binder systems with a complex organo-silica additive accompanied by the intensive formation of hydrated new substances is represented mainly by low-basic calcium hydrosilicates, which contribute to micro-reinforcement of cement stone, while strengthening its structure and improving adhesion to the aggregate, which is one of the prerequisites for obtaining durable lightweight concrete with increased operational characteristics.

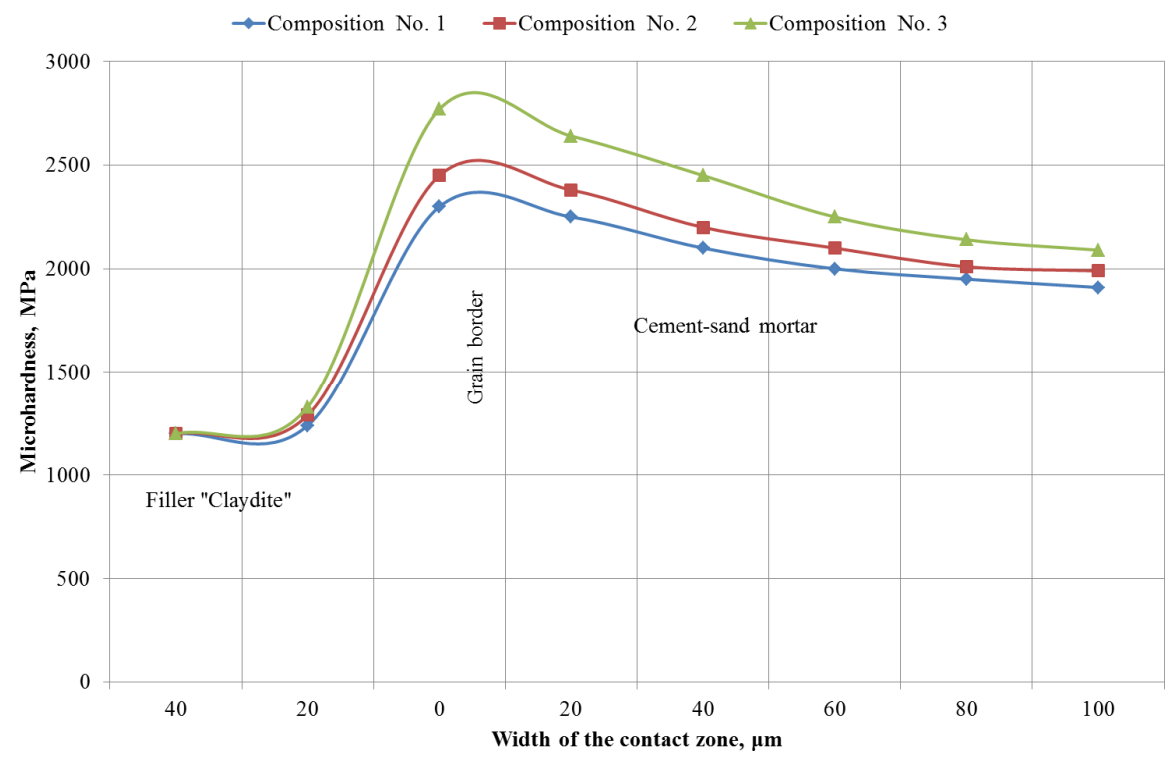

Fig. 2. Change of the microhardness of the contact zone "binding - aggregate" for lightweight concrete: No. 1 - control mix; No. 2 - modified with superplasticizer "SikaPlast 555W"; No. 3 modified with a complex organo-silica additive on the basis of this superplasticizer and fine-ground tripoli earth.

On the photos of the surface of the artificial stone chip on the basis of Portland cement modified with a complex organo-silica additive fibrous formations and partially recrystallized needle crystals of low-calcium hydrosilicates in the lamellae are clearly visible (Fig. 3), which provides the basis for obtaining high-strength lightweight concrete with a more homogeneous structure.

Thus, when Portland cement modified by a complex additive hardens, due to the reduction of $\mathrm{B} / \mathrm{C}$ in compressed conditions, there is a directed synthesis of crystallochemically similar compounds and layered reinforcement of the cement matrix with lamellar and needle-like new formation based on low-base calcium hydrosilicates of $\mathrm{CSH}$ (I), tobermorite $11.3 \AA$ together with platzolite and hydrogarnets that can aggregate and contribute to the formation of a more advanced microstructure of cement stone [21].

The presence in the structure of claydite gravel of isolated closed and open pores promotes penetration of the Portland cement paste into the structure of the expanded clay (due to the self-immolation effect), resulting in interaction between the aluminosilicate component of claydite and the products of hydration of Portland cement, which causes the formation of a stronger contact zone. At the same time, it is likely that in the composition of 
new formation, in addition to low-basic hydrosilicates of calcium will also be present hydroaluminosilicates, for example, hydrogelinitis.

To assess the performance of lightweight expanded clay concrete, its watertightness should be determined. Water absorption of concrete, as one of the factors of water resistance, can be reduced by increasing the density of the structure of concrete which is achieved by reducing the $\mathrm{W} / \mathrm{C}$ ratio, as well as the introduction into a concrete mix chemical and mineral additives. Concrete test results are given in Table 4.

a)

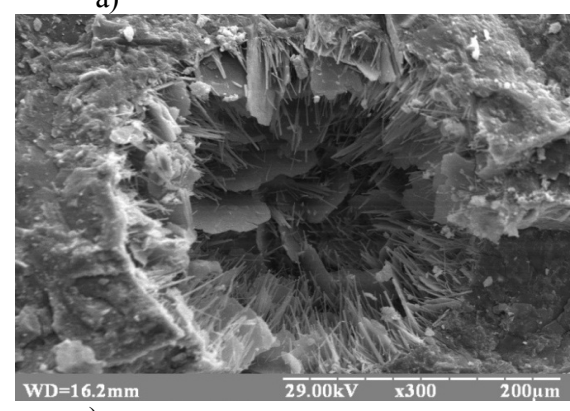

c)

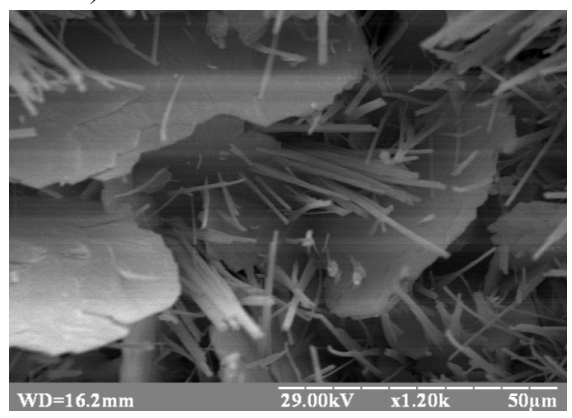

b)

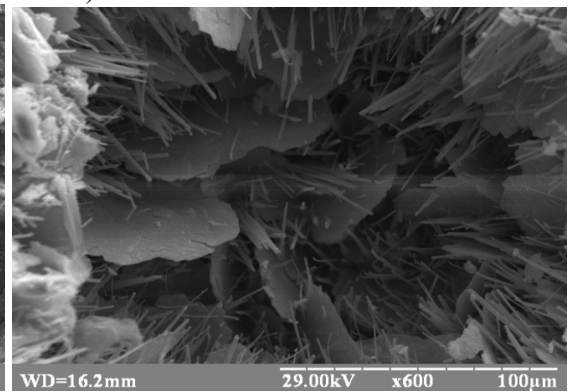

d)

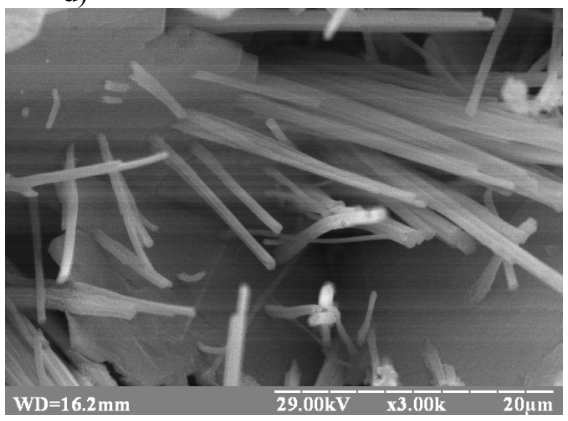

Fig. 3. Photographs of microstructure of cement stone, modified with a complex additive containing polycarboxylate superplasticizer "SikaPlast 555W" and ground shaking tripoli earth after 365 days of hardening: zoom (a) ×300 times; (b) $\times 600$ times; (c) $\times 1,200$ times; (d) $\times 3,000$ times.

The analysis of the data obtained indicates that the complex organo-silica additive developed as a part of lightweight expanded aggregate clay concrete reduces water absorption by $32.6 \%$ and reduces volumetric open porosity by $33.5 \%$ vs. the additiveless composition, and as a result leads to the formation of optimal structure of concrete.

Waterproofness of concrete plays a significant role in ensuring its water resistance. It is measured by the value of hydrostatic pressure, passing in water through the concrete while it begins to soak. Concrete watertightness is reduced by the use of some technological techniques that increase the density of the structure of both cement stone and concrete in general, which is achieved by lowering the $\mathrm{W} / \mathrm{C}$ ratio and optimizing granulometric composition. Test results are presented in Table 5. 
Table 4. Test results of expanded clay aggregate concrete samples tests for water absorption.

\begin{tabular}{|c|c|c|c|c|c|c|c|c|}
\hline \multirow[b]{2}{*}{$\begin{array}{l}\dot{z} \\
\dot{x}\end{array}$} & \multicolumn{5}{|c|}{ Content of component, wt. \% } & \multirow[b]{2}{*}{$\begin{array}{c}\text { Average } \\
\text { density, } \\
\mathrm{kg} / \mathrm{m}^{3}\end{array}$} & \multirow[b]{2}{*}{$\begin{array}{c}\text { Water } \\
\text { absorption, } \\
\text { W, \% }\end{array}$} & \multirow[b]{2}{*}{ Open pores, $\%$} \\
\hline & 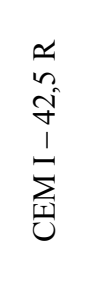 & 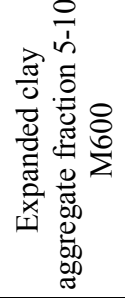 & 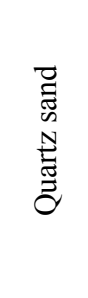 & 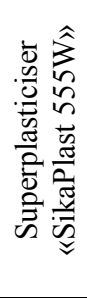 & 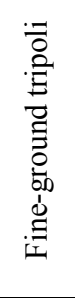 & & & \\
\hline 1 & 19.2 & 23.83 & 56.97 & - & - & 1853 & 3.74 & 7.04 \\
\hline 2 & 19.14 & 23.77 & 56.83 & 0.26 & - & 1858 & 3.2 & 5.94 \\
\hline 3 & 17.4 & 23.77 & 56.83 & 0.26 & 1.74 & 1859 & 2.52 & 4.68 \\
\hline
\end{tabular}

In the study of waterptightness of lightweight expanded clay concrete it was established that modification only with superplasticizer provides an increase in watertightness by $13 \%$, while the introduction of a complex organo-silica additive contributes to an increase in watertightness by $37 \%$, compared with the control composition, which corresponds to the grade of watertightness W8 (Table 5).

Table 5. Determination of watertightness of different lightweight expanded clay concrete mixtures.

\begin{tabular}{|c|c|c|c|c|c|c|c|c|c|}
\hline \multirow[b]{2}{*}{$\begin{array}{l}\dot{z} \\
\stackrel{x}{\Sigma}\end{array}$} & \multicolumn{5}{|c|}{ Content of component, wt. \% } & \multirow[b]{2}{*}{ 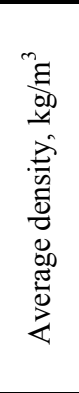 } & \multirow[b]{2}{*}{ 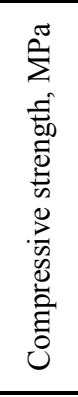 } & \multirow[b]{2}{*}{ 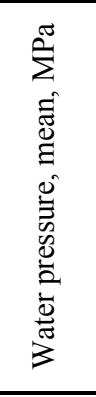 } & \multirow[b]{2}{*}{ 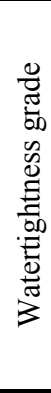 } \\
\hline & 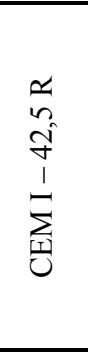 & 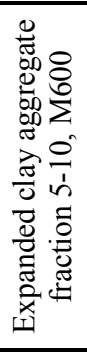 & $\begin{array}{l}\vec{Z} \\
\text { W } \\
\text { N } \\
\text { E्ञ } \\
\vec{\Xi}\end{array}$ & 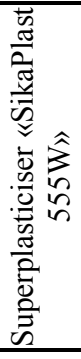 & 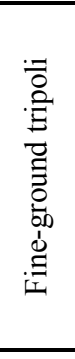 & & & & \\
\hline 1 & 19.2 & 23.83 & 56.97 & - & - & 1891 & 23.9 & 0.605 & W6 \\
\hline 2 & 19.14 & 23.77 & 56.83 & 0.26 & - & 1897 & 34.6 & 0.688 & W6 \\
\hline 3 & 17.4 & 23.77 & 56.83 & 0.26 & 1.74 & 1898 & 43.3 & 0.832 & W8 \\
\hline
\end{tabular}

Increasing watertightness can be explained by the predetermined formation of hydration products and reducing the open porosity of clay concrete, which confirms the effectiveness of using this complex additive.

Assessing the physical and mechanical characteristics of modified expanded clay concrete, it is possible to predict that the developed concrete compositions will have improved special properties such as frost resistance, corrosion resistance, as well as reduced shrinkage deformation rates, which to a certain extent depend on water absorption, watertightness and open porosity.

Tests of modified concrete's frost resistance was carried out in accordance with DSTU B V.2.7-49-96 [22], using an accelerated procedure in a 5\% sodium chloride solution at a temperature of $-50^{\circ} \mathrm{C}$. According to the requirements of normative documents, strength loss 
of specimens that have been under a certain number of cycles of freezing-thawing, should not exceed $5 \%$. The results of studies are presented in Table 6.

The obtained data shows that the control mix of expanded clay concrete on the basis of Portland cement CEM I - 42.5 R provides the frost resistance grade of concrete F200, because the strength loss after 6 cycles of alternating freezing-thawing was $6.82 \%$, exceeding $5 \%$.

Modification of expanded clay concrete with the addition of superplasticizer "SikaPlast 555W" (mix No. 2, Table 6), provides frost resistance F300: strength loss after the 10th cycle of alternating freezing-thawing was $5.61 \%$.

After modification of the expanded clay concrete with a complex additive based on the superplasticizer "SikaPlast 555W" and fine-ground diatomite (mix No. 3, Table 6), there is a rise in frost resistance up to F400, which is confirmed by the results of tests. Loss of strength after the 14 th cycle of alternating freezing-thawing was $5 \%$.

The increase of frost resistance of expanded clay concrete on the basis of Portland cement, modified by a complex additive, can be explained by the formation of advanced pore structure and a decrease in the volume of open capillary pores of the material, which provides a smaller amount of ice formed in the pores of concrete at negative temperatures and, accordingly, a decrease in the values of emerging stress forces in the structure of the material.

Table 6. Comparison of frost resistance of expanded clay concrete of different composition.

\begin{tabular}{|c|c|c|c|c|c|c|c|c|c|}
\hline \multirow{4}{*}{$\begin{array}{l}\dot{\partial} \\
\dot{x} \\
\dot{z}\end{array}$} & \multicolumn{5}{|c|}{ Content of component, wt. \% } & \multirow{2}{*}{\multicolumn{3}{|c|}{$\begin{array}{l}\text { Strength loss, } \% \text { after } \\
\text { accelerated methodology } \\
\text { freezing-thawing cycles }\end{array}$}} & \multirow{4}{*}{ 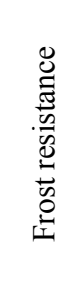 } \\
\hline & \multirow{3}{*}{ 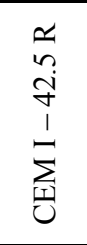 } & \multirow{3}{*}{ 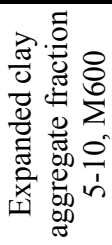 } & \multirow{3}{*}{ 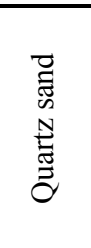 } & \multirow{3}{*}{ 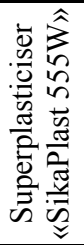 } & \multirow{3}{*}{ 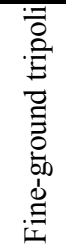 } & & & & \\
\hline & & & & & & & ber of & & \\
\hline & & & & & & 6 & 10 & 14 & \\
\hline 1 & 19.2 & 23.83 & 56.97 & - & - & -6.82 & - & - & F200 \\
\hline 2 & 19.14 & 23.77 & 56.83 & 0.26 & - & - & -5.61 & - & F300 \\
\hline 3 & 17.4 & 23.77 & 56.83 & 0.26 & 1.74 & - & - & -5.00 & F400 \\
\hline
\end{tabular}

The evaluation of the corrosion resistance of concrete was carried out according to the method [23-25]. Samples were made in size $10 \times 10 \times 10 \mathrm{~cm}$, which lasted 24 hours under normal conditions, and then in water. After 28 days of storage, samples were immersed in aggressive environments. Test specimens that were in aggressive environments were carried out after 180 days. Corrosion resistance was determined by the coefficient of corrosion resistance Kc, which is equal to the ratio of the strength of the samples after holding in an aggressive solution (Ragr) to the strength limit of the control samples that were tested at the moment of immersion of the basic samples in the solution (Ro). According to this technique, samples are corrosion-resistant, if, after testing at the age of 180 days, the coefficient of corrosion resistance is $\mathrm{Kc} \geq 0.8$.

Control samples of expanded clay concrete and comparative samples were selected for corrosion studies, modified only with superplasticizer and also a complex organo-silica additive. Taking into account possible operating conditions, the corrosion resistance of concrete was investigated in saline solutions, namely in $5 \%$ by weight sodium sulfate solution, $5 \%$ by weight of ammonium sulfate solution and $1 \%$ by weight magnesium sulfate solution. 
The residual strength of samples after exposure in aggressive environments for 180 days is given in Table 7, and the results of calculations of the coefficients of corrosion resistance of the investigated samples are presented in Fig. 4.

The analysis of the results suggests that the expanded clay concrete based on the Portland cement binder composition, modified by the additive based on the SikaPlast 555W polycarboxylate superplasticizer and the fine-ground tripoli earth, have rather high coefficients of corrosion resistance compared to the pure Portland cement compositions (Fig. 4, mix No. 3).

The value of $\mathrm{K}_{\mathrm{c}}$ of Portland cement clay concrete, modified with a complex additive, in magnesium sulfate solutions increases by 10 to $14 \%$ vs. the additiveless composition. In sodium sulfate solutions, this indicator increases by 7.5 to $12.5 \%$, and in ammonium sulphate solutions - by 15 to $24 \%$, compared with the additiveless composition.

The increase in the corrosion resistance of expanded clay concrete can be explained by a decrease in the penetration of aggressive sulfate ions inside the specimens by reducing the open porosity and reducing water absorption, which is achieved by compacting the structure of Portland cement stone and predicted synthesis of increased amount of lowbasic calcium hydrosilicates.

Table 7. Change in the strength of expanded clay concrete after storage in aggressive environments.

\begin{tabular}{|c|c|c|c|c|c|c|c|c|c|}
\hline \multirow{3}{*}{$\stackrel{\dot{z}}{\dot{z}}$} & \multicolumn{5}{|c|}{ Content of component, wt. \% } & \multirow{3}{*}{ 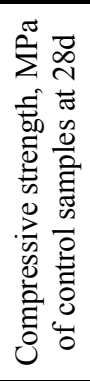 } & \multirow{2}{*}{\multicolumn{3}{|c|}{$\begin{array}{l}\text { Compressive strength, MPa } \\
\text { after aggressive environment } \\
\text { storage at } 180 \mathrm{~d}\end{array}$}} \\
\hline & \multirow{2}{*}{ 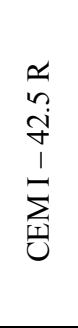 } & \multirow{2}{*}{ 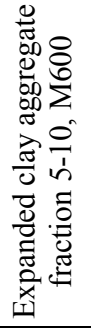 } & \multirow{2}{*}{ 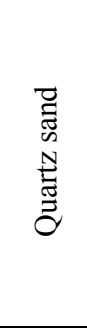 } & \multirow{2}{*}{ 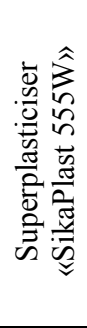 } & \multirow{2}{*}{ 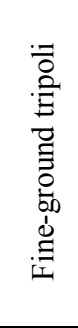 } & & & & \\
\hline & & & & & & & 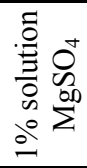 & 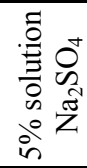 & 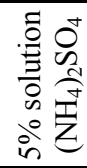 \\
\hline 1 & 19.2 & 23.83 & 56.97 & - & - & 22.9 & 19.69 & 18.32 & 16.03 \\
\hline 2 & 19.14 & 23.77 & 56.83 & 0.26 & - & 34.9 & 33.16 & 30.02 & 28.27 \\
\hline 3 & 17.4 & 23.77 & 56.83 & 0.26 & 1.74 & 38.2 & 37.44 & 34.38 & 33.23 \\
\hline
\end{tabular}


口Composition No. 1 aCompositionNo.2 aComposition No.3

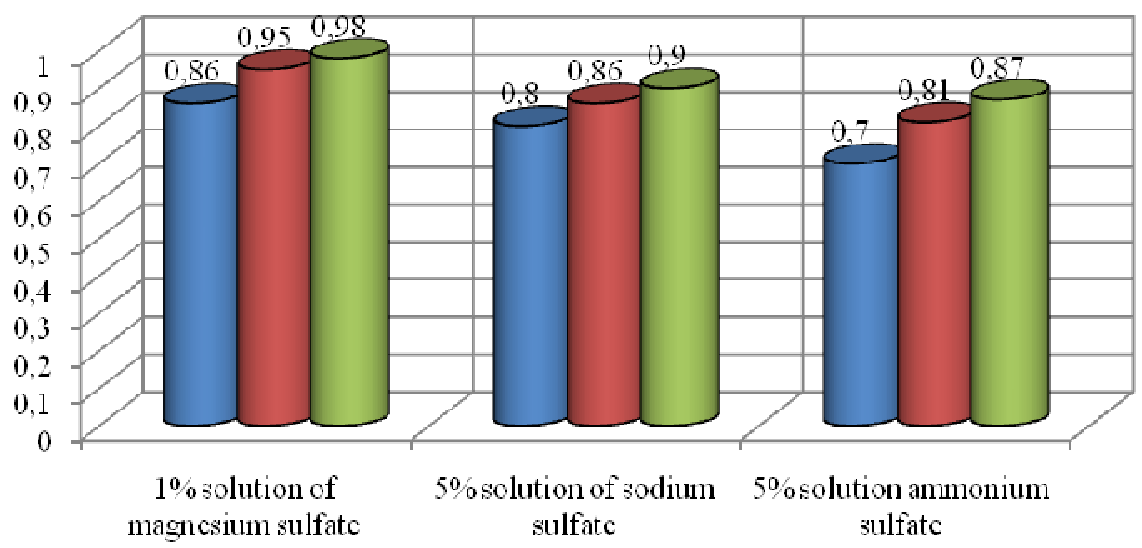

Fig. 4 Comparison of coefficients of corrosion resistance $\mathrm{K}_{\mathrm{s}}$ of expanded clay concrete of different composition (according to Table 7) after 180 days aging in aggressive environments: $1 \%-\mathrm{MgSO}_{4}$; $5 \%-\mathrm{Na}_{2} \mathrm{SO}_{4}$ and $5 \%-\left(\mathrm{NH}_{4}\right)_{2} \mathrm{SO}_{4}$.

An important characteristic of concrete is the value of relative shrinkage, which is defined as the arithmetic mean of the reduction in the size of the sample relative to the initial reference [26]. As known, one of the reasons for shrinkage of Portland cement systems are three-dimensional changes in the gel of a cement stone during drying, which depend on the mineralogical composition of the system, the fineness of cement grinding, conditions and hardening time. At the micro level, the amount of shrinkage depends, first of all, on the ratio of crystalline and gel phases in the products of hydration of the binding composition. The study of the change of relative shrinkage of expanded aggregate clay is given in Table 8 and in Fig. 5.

Table 8. Comparison of relative shrinkage of expanded clay concrete of different composition.

\begin{tabular}{|c|c|c|c|c|c|c|c|c|c|c|c|c|}
\hline \multirow{3}{*}{$\begin{array}{l}\dot{z} \\
\stackrel{x}{\Sigma}\end{array}$} & \multicolumn{5}{|c|}{ Content of component, wt. $\%$} & & & & & & & \\
\hline & \multirow{2}{*}{ 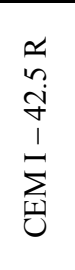 } & \multirow{2}{*}{ 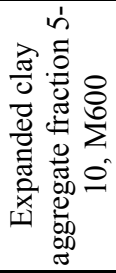 } & \multirow{2}{*}{ 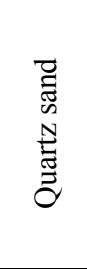 } & \multirow{2}{*}{ 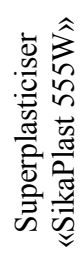 } & \multirow{2}{*}{ 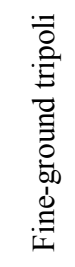 } & \multicolumn{7}{|c|}{$\begin{array}{l}\text { Kinetics of relative shrinkage of clay concrete, } \\
\qquad \varepsilon(\mathrm{t}) \cdot 10^{4}, \text { after days }\end{array}$} \\
\hline & & & & & & 3 & 7 & 14 & 21 & 28 & 60 & 90 \\
\hline 1 & 19.2 & 23.83 & 56.97 & - & - & 1.49 & 4.98 & 7.21 & 7.71 & 7.71 & 7.76 & 7.76 \\
\hline 2 & 19.14 & 23.77 & 56.83 & 0.26 & - & 0.99 & 4.95 & 6.44 & 6.93 & 6.93 & 6.98 & 6.98 \\
\hline 3 & 17.4 & 23.77 & 56.83 & 0.26 & 1.74 & 0.74 & 4.46 & 5.94 & 6.44 & 6.44 & 6.49 & 6.49 \\
\hline
\end{tabular}

In the study of changes of relative shrinkage of the expanded clay concrete of the above compositions, it was found that the introduction of the admixture of the polycarboxylate superplasticizer "SikaPlast $555 \mathrm{~W}$ " leads to a reduction of shrinkage by 10 to $12 \%$, while the introduction of a complex organo-silica additive reduces this index by 16 to $19 \%$ vs. the control mix. 


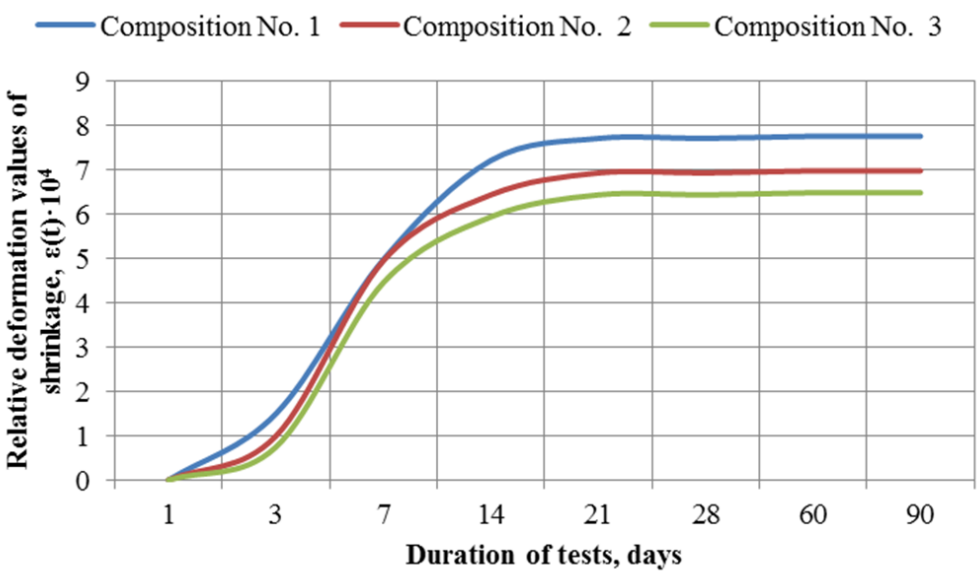

Fig. 5. Comparison of deformations of shrinkage of expanded clay concrete (mixes according to Table 8).

It is known that according to the normative documents for lightweight concrete shrinkage deformation can reach $1 \mathrm{~mm} / \mathrm{m}$ [26-30]. Thus, the deformation of shrinkage of the additive compositions at the age of 90 days is $0.776 \mathrm{~mm} / \mathrm{m}$, whereas modification with a complex additive reduces this index by $16 \%$ and is $0.649 \mathrm{~mm} / \mathrm{m}$ (Table 8 and Fig. 5).

The achieved effect of reducing shrinkage deformation can be explained by the directed formation of low-base calcium hydrosilicates in hydration products.

\section{Results discussion}

The influence of various grades of claydite gravel on the strength characteristics of lightweight concrete is investigated and it is shown that the use of concrete on the basis of expanded clay aggregate M600 is the most suitable for monolithic construction. It is shown that the highest values of compressive strength increase are associated with concrete mixtures based on expanded clay aggregate (M600), modified with a complex organo-silica based additive based on a polycarboxylate superplasticizer "SikaPlast 555W" in the amount of $1.5 \%$ and a fine-groung tripoli earth in an amount of $10 \%$ by weight while the intensification of compressive strength gain by 28 days reaches $66 \%$, and after 1 year to $60 \%$, compared with the control mixtures [18-20,32].

Analyzing the peculiarities of formation of the contact area "aggregate - binder" it was established that when the complex additive is introduced, the composition, gabitius of tumors and the intensity of the process of crystallization in the systems under consideration are changed. The influence of the complex additive on the peculiarities of the formation of the micro-, meso- and macrostructure has been established and a positive role in the synthesis of the strength of crystallochemical low-base calcium hydrosilicates is confirmed, which, in combination with hydroaluminosilicates, which are formed over time, provides a dense bonding and adhesion of the aggregate to the penetrating binder in the pore space of the aggregate grain.

It can also be noted that the use of expanded clay concrete is constantly expanding due to its physical, mechanical and thermal characteristics. For example, Cambio company combines these properties and has created effective expanded clay concrete blocks for the residental construction, which allows you to reduce the cost of construction by $30 \%$ and accelerate the construction time by 3 times [31]. 
According to the results of the study carried out in the batching plant «Budindustriya$1 »$, a production test of total volume of $120 \mathrm{~m} 3$ of expanded clay concrete, based on Portland cement modified with a complex organo-silica additive, that was used in the construction of Atlant 2 residential complex, was conducted. The full compliance of the properties of expanded clay aggregate based on Portland cement modified with a complex organo-silica additive, in the actual conditions of production and operation, has been confirmed, which testifies to their high efficiency and functionality in high-rise construction. The economic effect of the implementation of the developed concrete composition was UAH 90.25 for $1 \mathrm{~m}^{3}$ of concrete.

\section{Conclusion}

Developed mixes of expanded clay concrete of high strength LC 20/22 to LC 50/55 (DSTU B V.2.7-176: 2008) on the basis of Portland cement, modified with a complex organo-silica additive. It is shown that the introduction of a complex additive provide increasing in durability of expanded clay aggregate concrete at all stages of curing, increases the watertightness of W6 to W8, increases the frost resistance to F400, increases the coefficient of corrosion resistance Ks by 7.5 to $24 \%$, vs. the additiveless composition. It was also shown that the introduction of a complex organo-silica additive reduces the relative shrinkage by 16 to $19 \%$, compared with the control composition, which allows using high strength lightweight expanded clay concrete in residential construction.

\section{References}

1. V. H. Batrakov. Modyfikovani betony. Teoryya y praktyka, yzd. 2-e, pererabotannoe y dopolnennoe (M., 1998)

2. YU. M. Bazhenov et al. Modyfytsyrovannye vysokokachestvennye betony (M, Yzd-vo ASV, 2006)

3. L. I. Dvorkyn, Tsementni betony $z$ mineralnymy napovnyuvachamy (Kyyiv, Budivelnyk, 1991)

4. Y. A. Yvanov, Lehkye betony na shtuchnykh porystykh zapolnytelyakh (M., Stroyyzdat, 1993)

5. T.M Shtol, Tekhnolohiya keramzytobetonnykh vyrobiv na horyachomu zapovnyuvachi (M., Stroyyzdat, 1986)

6. L.P. Orentlykher, Betony na porystykh napovnyuvachakh u zbirnykh zhelezobetonnykh konstruktsiyakh (M., Stroyyzdat, 1983)

7. Rossinolo Dzh. A., Ahnesini M.V.S., Morayev YU.A. Tsem Kon Compo., 2003. №25. - S. 77-82.

8. Vey Tionh-Khuan. Nedavni podiyi v lehkykh vysokomitsnykh betonakh z ahrehatamy ta bez nykh", Tretye mizhnarodna konferentsiya z budivelnykh materialiv: produktyvnist, innovatsiyi ta strukturni naslidky, Universytet Brytanskoyi Kolumbiyi, 22-24 (Vankuver, Kanada, 2005)

9. Erhul Yasar, Kenhiz Dyuran Atis, Alaettyn Kilich, Khasan Hulsen, Sylovi vlastyvosti lehkoho betonu, vyhotovleni z bazaltovoyi pemzy ta lyutserny. Materialy Lysty, № 57, 2267-2270 (2003)

10. Dzhamal Alduay, Khalyd Alshalekh, r-n Naseer Khak, Khalid Ellayity Lehkyy beton $u$ haryachykh pryberezhnykh rayonakh. Tsementy ta betonni kompozyty, T. 21, 5-6, 453-458 (1999) 
11. K H. Al-Khayat, M.N. Khake, Doslidzhennya tsementu ta betonu, T. 28, 6, 859-866 (1998)

12. Padam Shafih, Mokhd Zamin Yumaat, Khilli Makhmud. Budivnytstvo ta budivelni materialy, T. 25, 4, 1848-1853 (2011)

13. Niyazi Uhur Kokal, T. Ozutaran, Materialy ta dyzayn, T. 32, 4, 2396-2403 (2011)

14. Uhu Kosta, Eduardo Khulio, Lourenkho J. Budivelni ta budivelni materialy, 35, 84-91 (2012)

15. M.A. Sannitskyy Enerhozberihayuchi tekhnolohiyi v budivnytstvi: navch. Posibnyk. (Lviv, Vydavnytstvo Lvivskoyi politekhniky, 2012)

16. A. Plugin, E. Dedeneva, T. Kostyuk, D. Bondarenko, O. Demina, Matec Web of Conference, 116, 01010 (2017)

17. O. Borziak, S. Vandolovskyi, V. Chajka, V. Perestiuk, O. Romanenko, Matec Web of Conference, 116, 01001 (2017)

18. K.K. Pushkarova, O.A. Honchar, K.O. Kaveryn, Zb. nauk. pratsi «Budivelni materialy, vyroby ta sanitarna tekhnika», 52, 43-48 (2014)

19. K.O. Kaveryn, Zb. nauk. pratsi «Budivelni materialy, vyroby ta sanitarna tekhnika», 56, 47-54 (2015)

20. K.K. Pushkarova, K.O. Kaveryn, Zbirnyk naukovykh prats «Resursokomisni materialy, konstruktsiyi, budivli ta sporudy», 33, 75-83 (2016)

21. K. K. Pushkarova, K. O. Kaverin, D. O. Kalatayevskyy, Skhidnoyevropeyskyy zhurnal pidpryyemstv pidpryyemstva, 5 (77), 42-51 (2015)

22. DSTU B V.2.7-49-96. Budivelni materialy. Betony Metody vyznachennya morozostiykosti. Pryskoreni metody vyznachennya morozostiykosti pry bahatorazovomu zamorozhuvanni ta vidtochenni, Derzhavnyy standart Ukrayiny (Kyyiv, Derzhkommistobuduvannya Ukrayiny, 1997)

23. M.YU. Leshchynskyy, Yspytanyya betona (M., Stroyyzdat, 1980)

24. DSTU B V.2.6-145: 2011 (HOST 31384: 2008, NEQ). Zakhyst betonnykh $i$ zalizobetonnykh konstruktsiy vid koroziyi. Zahalni tekhnichni vymohy, Derzhavnyy standart Ukrayiny (Kyyiv, Minrehionbud Ukrayiny, 2010)

25. DSTU B V.2.6-181: 2011 (HOST 31383: 2008, NEQ). Zakhyst betonnykh $i$ zalizobetonnykh konstruktsiy vid koroziyi. Metody vyprobuvan, Derzhavnyy standart Ukrayiny (Kyyiv, Minrehionbud Ukrayiny, 2011)

26. DSTU B V.2.7-216: 2009. Budivelni materialy. Betony Metody vyznachennya deformatsiy usadky ta skorboty, Derzhavnyy standart Ukrayiny (Kyyiv, Minrehionbud Ukrayiny, 2010)

27. H.S. Solopova, Mizhnarodnyy naukovyy zhurnal «Symvol nauky», 12, 81-82 (2015)

28. K.S. Karapetyan Osoblyvosti protsesiv kozatstva ta usadok lehkykh ta inshykh novykh vydiv betoniv. Polzuchest $i$ usadka betonu ta zhelezobetonnykh konstruktsiy (M., Stroyyzdat, 1976)

29. YU.H. Moskalkova, Nauka ta budivnytstvo, 3, 40-43 (2017)

30. S.O. Krovyakov, Nauka i budivnytstvo, 3, 50-58 (2017)

31. V.P. Kholodnyuk, Sbirnyk naukovykh prats «Budivelni materialy», 5-7 (2016)

32. K.K. Pushkarova, Mizhnarodnyy naukovo-vyrobnychyy zhurnal "Keramika: nauka i zhyttya", 1 (34), 32-41 (2017) 